\title{
ROLE OF INTERNAL VARIABILITY OF CLIMATE SYSTEM IN INCREASE OF AIR TEMPERATURE IN WROCŁAW (POLAND) IN THE YEARS 1951-2018
}

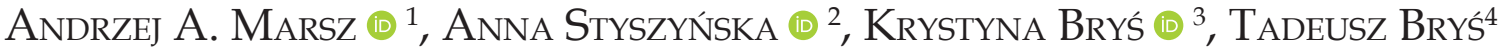 \\ ${ }^{1}$ Polish Geophysical Society, Baltic Branch, Gdynia, Poland \\ ${ }^{2}$ Association of Polish Climatologists, Warszawa, Poland \\ ${ }^{3}$ Institute of Environmental Protection and Development, Wroclaw University of Environmental and Life Science, \\ Wrocław, Poland \\ ${ }^{4}$ Polish Geophysical Society, Wrocław Division, Wrocław, Poland
}

Manuscript received: June 21, 2021

Revised version: August 24, 2021

\begin{abstract}
MARSZ A.A., STYSZYŃSKA A., BrYŚ K., BRYŚ T., 2021. Role of internal variability of climate system in increase of air temperature in Wrocław (Poland) in the years 1951-2018. Quaestiones Geographicae 40(3), Bogucki Wydawnictwo Naukowe, Poznań, pp. 109-124. 4 tables, 10 figs.

ABSTRACT: In the course of analysing the annual air temperature in Wrocław (TWr), a rapid change of the thermal regime was found between 1987 and 1989. TWr increased by $>1^{\circ} \mathrm{C}$, a strong, statistically significant positive trend emerged. The analysis of processes showed that strong warming in the cold season of the year (December-March) occurred as a result of an increase in the NAO intensity and warming in the warm season because of increased sunshine duration in Wrocław (ShWr). Multiple regression analysis has shown that the winter NAO Hurrell's index explains $15 \%$ of TWr variance, and the ShWr of the long-day (April-August) period 49\%, whereas radiative forcing 5.9\%. This indicates that the factors incidental to the internal variability of the climate system explain $64 \%$ of the TWr variability and the effect of increased $\mathrm{CO}_{2}$ concentration only $\sim 6 \%$. The reason for this rapid change of the thermal regime was a radical change in macro-circulation conditions in the Atlantic-European circular sector, which took place between 1988 and 1989. The heat, which is the cause of warming in Wrocław, comes from an increase in solar energy inflow (AprilAugust) and also is transported to Europe from the North Atlantic surface by atmospheric circulation (NAO). These results indicate that the role of $\mathrm{CO}_{2}$ in shaping the contemporary temperature increase is overestimated, whereas the internal variability of the climate system is underestimated.
\end{abstract}

KEYWORDS: air temperature trend, macro-circulation conditions, sunshine duration, $\mathrm{NAO}$, radiative forcing, $\mathrm{CO}_{2}$

Corresponding author: Andrzej A. Marsz,aam127@gmail.com

\section{Introduction and the purpose of research}

The air temperature in the Baltic Sea Basin and Central Europe, including Poland, has been growing rapidly and strongly over the last half century (Brázdil et al. 1996, Fortuniak et al. 2001, Kożuchowski, Żmudzka 2001, BACC 2008,
Philipona et al. 2009, Wójcik, Miętus 2014). The warmest region of Poland is Lower Silesia. This area is the south-western part of Poland and borders the Federal Republic of Germany to the west and the Czech Republic to the south, from which it is separated by Sudetes - the mountain range with the elevation of about 1000-1600 m a.s.l. (Fig. 1). Relatively high air temperature over 
the Lower Silesia area is conditioned by an unrestricted inflow of air masses from the west and the occurrence of foehn effects on the leeward slopes of Sudetes with air inflows from the southwest (Kwiatkowski 1975, Dubicka 1994, Dubicki et al. 2002, Ustrnul 2006, Ojrzyńska 2015).

The capital of Lower Silesia is Wrocław, where a very rapid increase in air temperature is observed. The increase in annual air temperature in Wrocław (TWr) in the years 1951-2018, expressed in degrees, calculated as the difference between the arithmetic means of the first five data (the years 1951-1955) and the last five data $(2014-2018)$ of this series, is $2.42^{\circ} \mathrm{C}$. The difference between these averages is highly significant $(p<0.001)$. The linear trend of the annual TWr in the years 1951-2018 is equal to $+0.034( \pm 0.005)^{\circ} \mathrm{C} \cdot$ year $^{-1}$ and is highly statistically significant $(p<0.001)$. This trend is much stronger than the global trend in air temperature $\left(+0.018^{\circ} \mathrm{C} \cdot\right.$ year $\left.^{-1}\right)$ or the northern hemisphere temperature trend $\left(+0.022^{\circ} \mathrm{C} \cdot\right.$ year $\left.^{-1}\right)$ between 1951 and 2017 as estimated by GISTEMP ${ }^{1}$. Temperature changes in Wrocław in the years 1951-2018 are very strongly correlated with changes in annual temperature at stations in Poland (correlation coefficients $\mathrm{r}$ from 0.81 to 0.97 ) and at stations located in Germany, Austria, the Czech Republic and Slovakia, less strongly but significantly with air temperature at stations located in Denmark, southern Sweden, Lithuania, Belarus and Ukraine. This proves that the temperature increase observed in Wrocław is not a local phenomenon but a manifestation of a process of supra-regional scale.

A strong rise in air temperature observed since the end of the 1980s is commonly explained by the effects of the so-called Anthropogenic Global Warming (AGW), which is, in turn, caused by an increase in the concentration of greenhouse gases in the atmosphere. $\mathrm{CO}_{2}$ concentration in the troposphere is particularly heavy and is undoubtedly an effect of human activity: the burning of fossil fuels, both hard coal and brown coal, as well as hydrocarbons. The remaining causes of this increase, such as deforestation, are also a result of human activity, although their role in shaping

Data source: ZonAnn.Ts.txt, https://data.giss.nasa. gov/gistemp/tabledata_v3/ZonAnn.Ts.txt. the increase in greenhouse gas concentration in the atmosphere is less significant.

Meanwhile, the analysis of the temperature course in Wrocław indicates that changes in $\mathrm{CO}_{2}$ concentration in the atmosphere do not explain a number of aspects of its variability - both shortand long-term, including discontinuity of this course and temperature increase much stronger than global or hemispheric one.

The latest IPCC (2014) account in the Synthesis Report in Figure 1.9 (p. 48) shows the contribution of individual components to the rise in air temperature in the years 1951-2010. The total contribution of anthropogenic factors is estimated at $+0.7( \pm 0.1)^{\circ} \mathrm{C}$, while the contribution of natural factors at $\pm 0.1^{\circ} \mathrm{C}$ and natural internal climate variability also at $\pm 0.1^{\circ} \mathrm{C}$. While the term internal climate variability is briefly explained in the Summary Report in order to understand what the authors of the IPCC (2014) meant by natural factors, we need to go back to the previous IPCC (2007), where in the Technical Summary in Figure TS.23 (p. 62), the authors explain that the only natural factors considered are changes in solar activity and volcanic eruptions. There is a very limited inventory of natural factors that can influence variability and climate change.

Therefore, the combined effect of natural factors coming from outside the climate system and climate variability as part of its internal dynamics, even if they were to operate in line with each other, should affect air temperature variations no more than by $\pm 0.2^{\circ} \mathrm{C}$. The contribution of natural intrinsic climate variability is assessed particularly modestly in the latest Report.

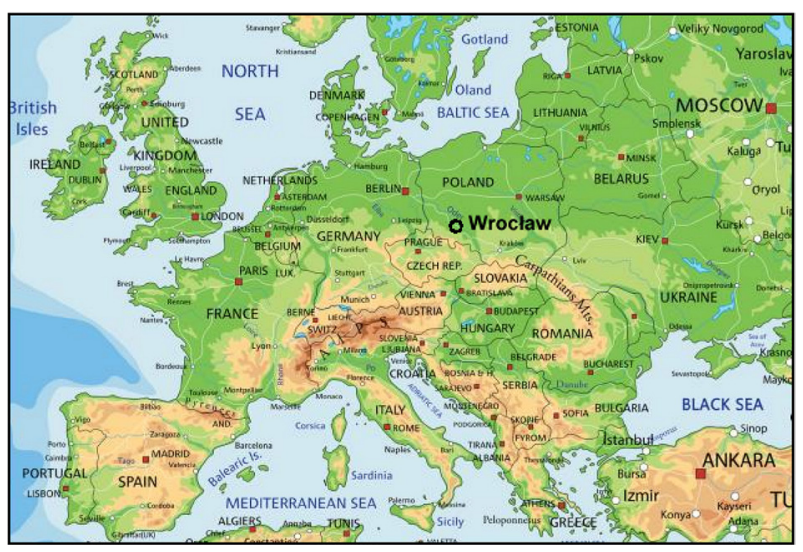

Fig. 1. The geographical position of Wrocław in Europe. 
Paleoclimatic and palaeoceanographic studies reveal that in the relatively recent past, around the last 2000 years, both global Earth's climate and the climate over particular areas have shown long-term variability similar to that observed today in terms of its scale. These changes occurred synchronously on the scale of the northern hemisphere, and not only in Europe and the North Atlantic environment, as previously assumed (Mann 2002, Oreopoulos et al. 2012). Quite frequently, in dozens of paleoclimatic studies, there are successive periods of varied thermal conditions in the northern hemisphere in the last 2000 years: the Roman Warm Period (warm; 100 BCE to 200-300 CE), the Dark Ages - by Büntgen et al. (2016) is called as Later Antique Little Ice Age (chilly; 400-700 CE), the Medieval Warm Period (warm; 900-1200-1300 CE), a multi-phase period of progressive cooling called the Little Ice Age ( 1500-1850 CE), with its thermal minimum in the second part of 18 th and the first decades of 19 th centuries and the period of contemporary climate $(\sim 1850$ to the present day), occasionally named the Anthropocene period or the industrial climate period. For example, deep into Asia (Altai), where all the above-mentioned climatic periods were documented, air temperature in the summer months during the Roman Warm Period (100 BCE-300 CE) was higher than nowadays (Nazarov et al. 2016). In Alaska, in the sub-arctic zone, Hu et al. (2001) find the same periods in the history of climate in the last twenty centuries and state that both in the Roman Warm Period and in the Medieval Warm Period, temperatures were higher or the same as today. The internal variability of the Earth's climate system is responsible for all these changes, because then the concentration of greenhouse gases, different than $\mathrm{H}_{2} \mathrm{O}$, in the atmosphere (with ca. $280 \mathrm{ppm}$ for $\mathrm{CO}_{2}$ ) was lesser than that present currently (with ca. $410 \mathrm{ppm}$ for $\mathrm{CO}_{2}$ ). Therefore, there are no compelling reasons to believe that the above-mentioned variability merely stopped in the second half of the 20th and early 21st century, and all or almost all the observed changes in air temperature are linked to increased concentration of greenhouse gases in the atmosphere, which, in turn, leads to AGW.

Thereby, the shown premises direct an attempt to explain grounds of the air temperature increase in Wrocław to study the role of internal dynamics of the climatic system as a reason of the observed air temperature changes.

This study aims to assess the role of internal variability of the climate system in shaping the variability of $\mathrm{TWr}$, a city with long-term meteorological observations. Several weather stations, not too distant from one another, operating at the same time in an area of little hypsometric differentiation (Dubicka, Pyka 2001) have enabled continuous record of changes in climatic elements after 1950. If we compare data from weather stations in Wrocław, we can see that they are very strongly correlated. Accordingly, regardless of inevitable minor differences resulting from the impact of the closest surroundings of these stations, they provide a highly reliable record of changes in the climate of Wrocław occurring from 1951 to the present day. Due to a strong increase in air temperature in recent years, it was decided to go beyond the analysed years 1951-2010 in the IPCC (2014) and cover the years 1951-2018 by the research in order to include the processes taking place presently in this research.

\section{Source of the data and methods}

In the analyses carried out, time series of values of meteorological elements with monthly resolution, characterising climatic conditions of Wrocław, were used. The annual values are calculated as simple arithmetic averages in a calendar year (January-December). The values of monthly air temperature, monthly sums of precipitation, number of days with precipitation, atmospheric pressure, relative humidity and general cloud cover come from official data collected by the state observation network of the Institute of Meteorology and Water Management (IMGW) at the meteorological station Wrocław (Czernecki et al. 2020). These series were taken from the database Meteorological data: Averages and monthly totals, ver. $1.32^{2}$. The meteorological station of the IMGW Wrocław (airport station: Wrocław-Strachowice located in a western district of the city: $\varphi=51^{\circ} 06^{\prime} \mathrm{N}, \lambda=16^{\circ} 53^{\prime} \mathrm{E}$, $\mathrm{h}=120 \mathrm{~m}$ a.s.l.), from which a series of monthly

https:// meteomodel.pl/dane/historyczne-dane-pomiarowe/ 
air temperatures were collected, is outside the range of the urban heat island (Szymanowski 2004, 2005).

The long (the years 1791-2007) annual temperature series used comes from Bryś and Bryś (2010). It was supplemented by official data from the IMGW observation network until 2018. The monthly sunshine values for the years 1951-1960 come from the Meteorological Observatory of the Wrocław University located in WrocławBiskupin (east district of the city: $\varphi=51^{\circ} 06^{\prime} \mathrm{N}$, $\lambda=17^{\circ} 05^{\prime} \mathrm{E}, \mathrm{h}=116 \mathrm{~m}$ a.s.l.), for 1961-2018 from the Meteorological Observatory of the Wrocław University of Life Sciences located in WrocławSwojec (east district of the city: $\varphi=51^{\circ} 07^{\prime} \mathrm{N}$, $\lambda=17^{\circ} 10^{\prime} \mathrm{E}, \mathrm{h}=121 \mathrm{~m}$ a.s.1.) (Bryś et al. 2019). The two stations are separated in a straight line by a distance of about $5 \mathrm{~km}$. The series used in this work is a sequence connected from both these stations. Before the combination, these values were examined in detail for their homogeneity, and the result was positive.

An increase of the $\mathrm{CO}_{2}$ concentration in the atmosphere gives an additional flux of energy directed to the Earth's surface, which causes a rise in temperature. The IPCC $(2001,2007,2014)$ refers to this stream as radiative forcing. The radiative forcing values (hereinafter referred to as variable $\mathrm{DF} ; \mathrm{W} \cdot \mathrm{m}^{-2}$ ) were calculated from the series of annual concentrations of $\mathrm{CO}_{2}$ in the atmosphere using the formula (after IPCC (2001), chapter 6, tab. 6.2).

$$
\Delta \mathrm{F}=5.35 \ln \left(\mathrm{C} / \mathrm{C}_{0}\right)
$$

where:

- $\Delta \mathrm{F}$ - radiative forcing $\left(\mathrm{W} \cdot \mathrm{m}^{-2}\right)$,

- C - current concentration of $\mathrm{CO}_{2}$ in the atmosphere (ppm),

- $\mathrm{C}_{0}$ - concentration of $\mathrm{CO}_{2}$ in the pre-industrial era (280 ppm),

- $\ln$ - natural logarithm.

The series values of the average annual $\mathrm{CO}_{2}$ concentration from which DF was calculated for the years 1951-1958 are taken from the Global Mean Mixing Ratios: NASA GISS (Goddard Institute for Space Studies) Data ${ }^{3}$ and for the years 1959-2018 from the Mauna Loa $\mathrm{CO}_{2}$ annual mean

https:// data.giss.nasa.gov/modelforce/ghgases/Fig1A.ext.txt data: NOAA Earth System Research Laboratory, Global Monitoring Division" ${ }^{4}$

The calendar of frequency of the middle-tropospheric circulation types (500 hPa) according to the Wangengeim-Girs classification (Girs 1971, Girs, Kondratovich 1978) comes for the years 19512018 from Arctic and Antarctic Research Institute, Russian Federation, St. Petersburg. These data for 1951-2005 were taken from Annex 1 of the work of Dimitrieev and Belyazo (2006), whereas the unpublished data for the remaining years were obtained directly from AARI. Illustrations showing patterns of long-wave distribution in the $\mathrm{W}, \mathrm{E}$ and $C$ circulation types are not presented in this work; they are among others published in Barry and Carleton (2013) as Fig. 7.9 (p. 569). A series of the NAO (Hurrell 1995) winter (DJFM) station indicators (collection: DJFM North Atlantic Oscillation Index Station-Based) was downloaded from the NCAR UCAR (National Center for Atmospheric Research, University Corporation for Atmospheric Research) Climate Data Guide ${ }^{5}$.

The analysis methods used are standard statistical methods - correlation analysis, regression analysis and variance analysis. Statistical significance of correlation coefficients and estimated regression coefficients were determined by the Student's $t$-test and statistical significance of regression equations by the Fischer-Snedecor's F test. This paper does not discuss the factors influencing changes in air temperature, which are referred to in the IPCC (2014) as natural factors, i.e. the variable solar activity and volcanism. These come from outside the climate system and their activity can only modulate the variable waveforms courses of TWr (Fig. 2) generated by the climate system. However, they were considered in the analyses, but their contribution to the creation of TWr variability in the considered period is negligible, because the Total Solar Irradiance (TSI) contribution is $\sim 1 \%$ and the contribution of stratospheric volcanic aerosols is practically zero. The data sets used for these estimates were TSI reconstruction based on NRLTSI $2^{6}$ and the NASA GISS stratospheric aerosol optical depth at $550 \mathrm{~nm}^{7}$.

\footnotetext{
https://gml.noaa.gov/ccgg/trends/data.html

https://climatedataguide.ucar.edu/sites/default/ files/nao_station_djfm.txt

6 https://spot.colorado.edu/ koppg/TSI/Historical_ TSI_Reconstruction.txt

https://climexp.knmi.nl/data/isaod_gl.dat
} 


\section{Course of annual TWr in the years 1951-2018 against this course from the last decade of 18th century}

\section{The course of air temperature in the years 1791-2018}

Wrocław has a relatively long series of instrumental measurements of air temperature compared to other places in Europe. Temperature recording started in 1791 and has continued at several points within the city area. Individual sections of the measurement series were checked and homogenised (Bryś and Bryś 2010), creating a uniform sequence covering the years 1791-2007. This allows us to compare the course of the temperature curve in the years 1951-2018 (processed period) to the changes occurring in a much longer period. The analysis is based on the annual average air temperature - a comprehensive measure of thermal changes occurring in Wrocław.

Figure 2 shows the course of annual temperature changes in Wrocław in the years 1791-2018, presenting the values of annual temperature as deviations from the long-term average. The average annual temperature in this period is $8.68^{\circ} \mathrm{C}$, its $\mathrm{SD}$ being $1.05^{\circ} \mathrm{C}$.

The course of annual TWr reveals the occurrence of long-term, multi-decadal variability of considerable amplitude $\left(\min 5.5^{\circ} \mathrm{C}\right.$ in 1829 , max $11.2^{\circ} \mathrm{C}$ in 2018), which manifests itself as successive periods of cooling and warming. The

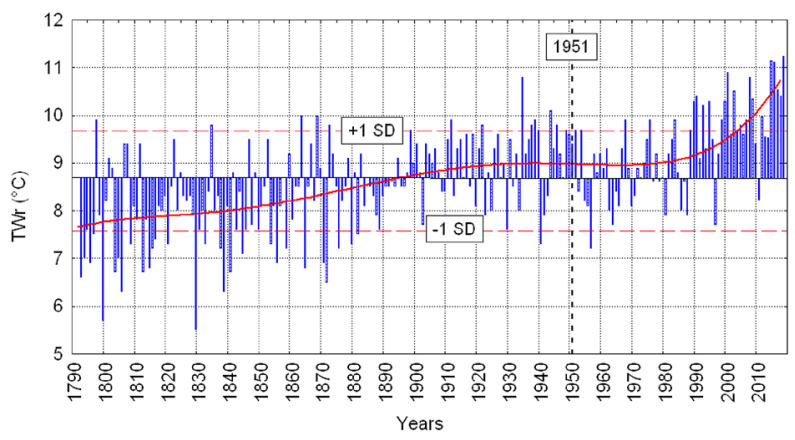

Fig. 2. The course of the annual air temperature in Wrocław (TWr) in the years 1791-2018 as a deviation from the long-term average. Continuous curve adjustment of the polynomial to the power of 5 to the empirical courses. The year 1951 (vertical dotted line) is marked, the initial year of the period 1951-2018 analysed in detail. Horizontal dashed lines mark limits of the \pm 1 SD. SD - standard deviation. changes take place against the background of a long-term (in fact on a centennial timescale) positive trend in a series of annual temperatures. The rate of temperature rise varies and is a function of time, and thus the actual trend is non-linear in its nature. The highest rate of temperature increase occurs at the end of the course, approximately since the turn of the 1980s and 1990s (Fig. 2). The linear trend, calculated for the years 1791-2018, has a value equal to $+0.0093( \pm 0.0009)^{\circ} \mathrm{C} \cdot$ year $^{-1}$ and explains for (adj. $R^{2}$ ) around $34 \%$ of variance in the annual temperature in these 228 years. As a result of the positive trend in the series of annual temperatures in Wrocław in the 1890s, the annual temperature relatively permanently assumed higher values than the long-term average (Fig. 2), and since the beginning of the 1990s, on average, it has remained at the level higher by +1SD than the multi-annual average.

\section{The course of annual air temperature in the years 1951-2018 and its peculiarity}

The period of 1951-2018, for which the analysis of the role of variability within the system in the shaping of temperature changes is made, is in the final part of the 228-year series and constitutes its warmest fragment. There is a strong $\left(+0.034( \pm 0.005)^{\circ} \mathrm{C}\right)$ and highly significant $(p<0.001)$ positive trend of the annual TWr calculated for these 68 years, what earlier in this paper it has only briefly mentioned.

The review of TWr supported by an analysis of the envelope of its variability band indicates that it is divided into two parts (Fig. 3). The boundary between two different periods in the course of temperature curve occurs between 1987 and 1989, when there is a rapid increase in annual temperature and a remarkable shift in the nature of its course. The year 1988 is taken as the boundary year between the two periods.

In the first period (1951-1988), differences between particular years are significant, the average temperature is lower than the multi-annual average of $1791-2018\left(+8.26^{\circ} \mathrm{C}\right)$, and the trend in the series is zero. In the second period (1988-2018), a strong $\left(+0.052( \pm 0.015)^{\circ} \mathrm{C} \cdot\right.$ year $\left.^{-1}\right)$ and statistically significant $(p=0.002)$ positive trend appear in $\mathrm{TWr}$, and the range of inter-annual variability is changing rapidly. The differences between successive years are then decreasing and, at the same 
time, the following years are getting warmer. The thermal regime change occurred suddenly, in 2-3 years, and has a radical character (Fig. 3) as a rapid transition, transferring the further course of TWr to a new initial level, $>1^{\circ}$ higher than the previous level. The changes in the annual temperature value and the range of variation between these periods are so large that TWr forms separate populations in both periods (Fig. 4).

Such course of the TWr values explains that a rapid temperature increase began after 1988, and the whole temperature increase in the considered period 1951-2018 occurred in its second part, that

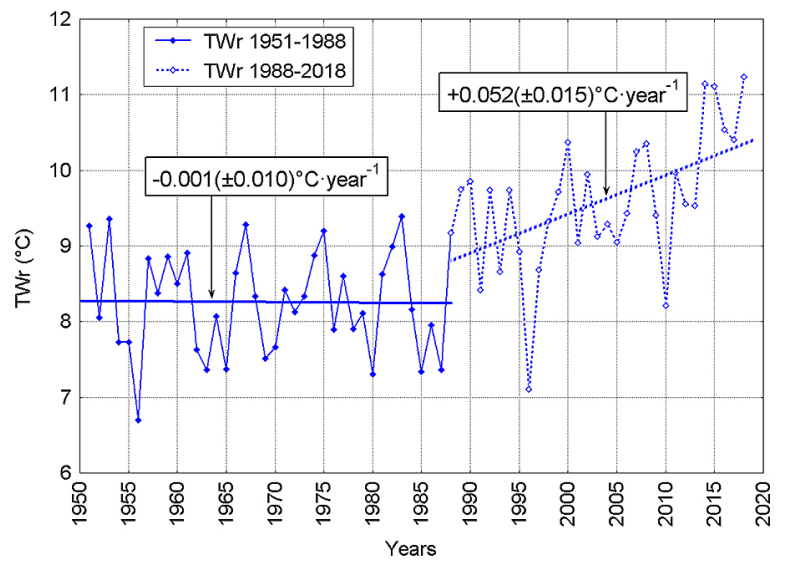

Fig. 3. The course of the annual air temperature in Wrocław (TWr) in the years 1951-2018. Significantly different courses in the periods 1951-1988 and 19882018 can be seen. Marked trends and their values in both periods.

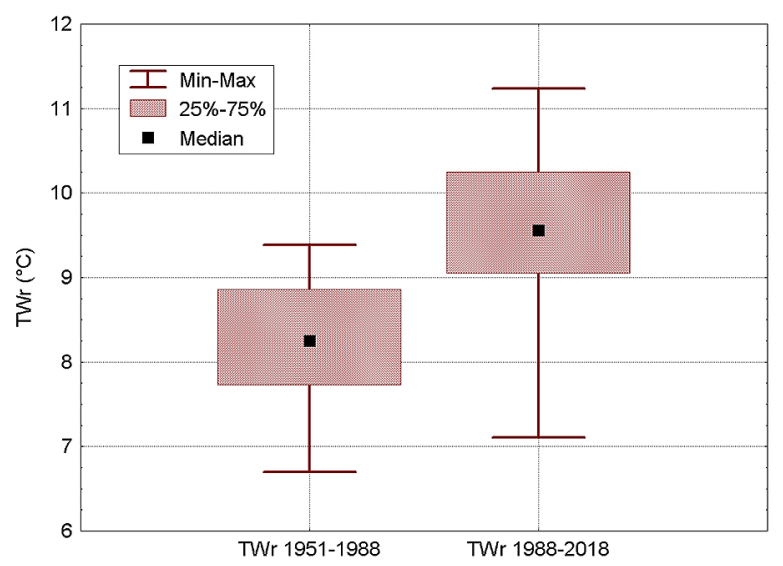

Fig. 4. Variation ranges of the annual air temperature in Wrocław (TWr) in both periods: 1951-1988 and 1988-2018. It appears noteworthy that in the second period, the lower limit of the second quartile is higher than the upper limit of the third quartile in the previous period, and the median in the second period is above the absolute maximum in the first period.

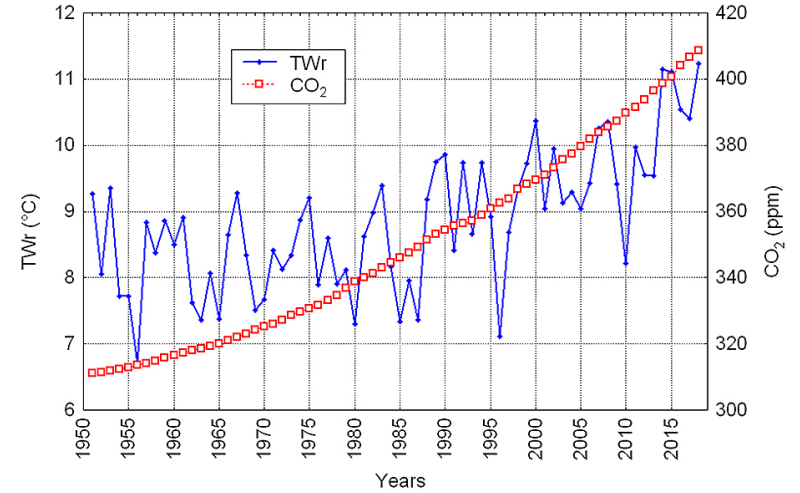

Fig. 5. The courses of the annual air temperature in Wrocław (TWr) and the average annual values of $\mathrm{CO}_{2}$ concentration in the atmosphere.

is, between 1988 and 2018. This course differs considerably from the monotonically increasing course of $\mathrm{CO}_{2}$ concentration in the atmosphere (Fig. 5).

This course of the TWr value explains that the rapid increase in temperature began after 1988, and the entire increase in temperature in the considered period of 1951-2018 occurred only in its second part, in 1988-2018, while the uniform linear trend TWr calculated for the period 1951-2018 does not reflect the actual course of changes TWr.

The trends in the course of TWr and $\mathrm{CO}_{2}$ concentration coincide only after 1988; earlier on, increasing $\mathrm{CO}_{2}$ concentration is not reflected in the long-term (38 years) course of temperature. Moreover, the short-term variability of both courses (Fig. 5) shows that the monotonous increase in $\mathrm{CO}_{2}$ concentration does not seem to be connected with the strong variability of TWr over the years. It follows that the reasons for the sudden change in the TWr regime after 1988 are also to be sought in the processes related to the internal dynamics of the climate system rather than in the processes associated with AGW.

\section{The factors affecting annual air temperature increase in Wrocław}

If we consider possible reasons for the increase in the annual TWr after 1988 from a purely thermodynamic point of view, a sensible conclusion is that the amount of heat must have increased in the atmosphere during the period in question. In addition, the increase in the amount of heat in the atmosphere must have occurred rapidly, in a 
relatively short time, within 2-3 years; and then it has been increasing progressively.

In general, an increase in the amount of heat over a research area can occur due to two factors:

1 . by a more frequent advection of air masses with increasing enthalpy as a consequence of atmospheric circulation influence (advection factor) or/and

2 . by changes in the net radiation of this area towards its growth (radiation factor).

In the last case, an increase in the heat resources may occur when the amount of solar energy reaching the ground increases or when heat loss from the atmosphere is reduced. The growth of radiation inflow to the ground may occur due to the limitation of the cloudiness and an increase of the sunshine duration (Sh), as well as an increase of the atmospheric transparency and/or an increase of the solar constant.

The changes in the solar constant which is a conventional measure of mean Total Solar Irradiance (TSI), i.e. solar energy reaching the upper boundary of the atmosphere, as a basic reason for air temperature increase after 1988 can be ignored. Differences in the amount of the solar constant, being a result of the variable solar activity are virtually insignificant, because it reaches only $1.7 \mathrm{~W} \cdot \mathrm{m}^{-2}$ (in the year 1680 , when the Maunder Minimum was $-1360.0 \mathrm{~W} \cdot \mathrm{m}^{-2}$ and maximum in the year $2002-1361.7 \mathrm{~W} \cdot \mathrm{m}^{-2}$, at the mean value - $1360.45 \mathrm{~W} \cdot \mathrm{m}^{-2}$; Kopp et al. 2016). In the examined period 1951-2018, they are on average lesser from $1 \mathrm{~W} \cdot \mathrm{m}^{-2}$; moreover, the course of TSI variability doesn't appear to be a reliable basis of their connections with the observed rapid increase of TWr after 1988. The changes in the stratospheric aerosol concentration (GISS stratospheric aerosol optical depth at $550 \mathrm{~nm}$ ) also do not show any significant connections with the course of TWr $(r=-0.15, p=0.231)$.

Limitation of heat loss may take place as a result of chemical changes in the atmosphere: an increase in the content of greenhouse gases in the atmosphere (mostly $\mathrm{CO}_{2}$ ) or an increase in cloud cover during the cold season of the year. In both cases, return radiation increases. Reduction of heat loss by increasing greenhouse gas concentration, mostly $\mathrm{CO}_{2}$, and hence a rise in annual temperature is nothing other than AGW. In this case, human activity is the cause of the change in the heat balance; this change is not brought about by any processes of changeability within the system. This indicates that despite the unsatisfactory explanation of the changes in TWr by the changes in $\mathrm{CO}_{2}$ concentration, the radiative forcing (DF) cannot be ignored in further considerations and estimates.

Studies into the factors resulting from the internal variability of the climate system in shaping variability of the annual air temperature require identification and selection of variables most strongly influencing the deviation in the annual temperature value from its idealised annual cycle resulting from the inflow of solar energy and heat brought in by advection.

\section{The radiation factor activity}

At a point with given geographical coordinates, potential solar energy inflow is the same on successive days in the year. A potential source of solar energy is defined as the amount of solar energy penetrating the atmosphere at its upper boundary on a given day. It is a function of the astronomical factors (length of a day, the Sun's height, which, in turn, are function of the Sun's declination and the latitude) and TSI values. Thus, both monthly and annual values of the potential solar radiation inflow, being daily totals in a given month or year, cannot differ from each other in successive years. Therefore, if the annual average temperature involves variation within the year, this variation, if caused by changes in the amount of solar energy supplied, with a relatively constant TSI value, must be brought about primarily by factors that interfere with the flow of solar energy to the Earth's surface at given geographical coordinates.

The basic factor regulating the flow of solar energy to the Earth's surface is cloudiness. Clouds are shaped by changing weather conditions or, alternatively, by the variability of synoptic situations. Internal processes of the climate system are manifested through this type of variability. Cloudiness is observed as general cloud cover $(\mathrm{N})$, both during the day and night, and then averaged to daily, monthly and eventually to annual values. Solar energy flows to the Earth's surface only during the day. For this reason, data on cloud cover do not provide fully reliable information about the amount of solar energy flowing to the Earth's surface. Correlation of monthly and 
annual values of general cloudiness in Wrocław with the same series of air temperature shows that such relation changes the sign into negative or positive during the year, and statistically significant correlations occur only in some months of the warm season (Table 1). Statistically significant relationships between annual cloudiness and annual temperature are missing.

Sunshine duration is a climatic element that informs us about the time of solar operation during a day, month or year. It considers the disturbing effect of cloud cover, but it does not inform us about the amount of energy coming in but only about the time span the energy was coming in. Statistically, it can be assumed that the amount of solar radiation flowing to the Earth's surface averaged in monthly or longer periods is related to the sunshine duration, because the greater the amount of Sh, the more solar energy comes to the ground. This relationship is described by the Angström-Prescott equation, and then

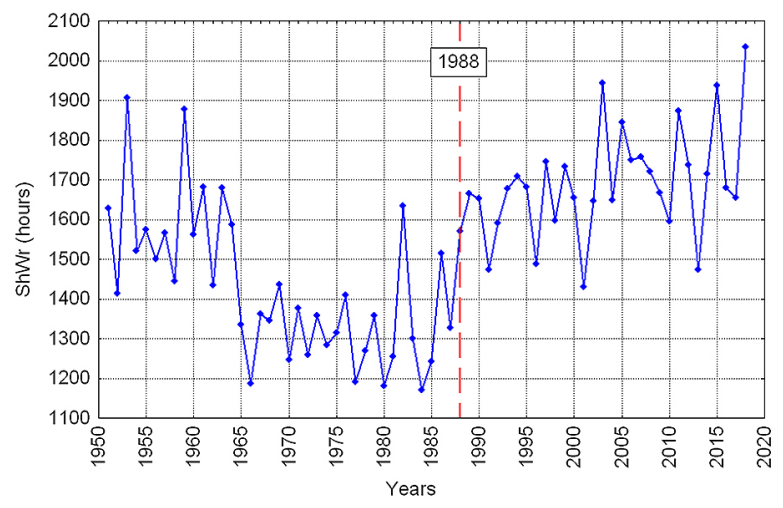

Fig. 6. The course of annual sunshine duration in Wroclaw ShWr. The vertical dashed line (1988) marks the moment of transition of significantly different courses of ShWr. transformed into a simpler form by Black et al. (1954), which allows estimating the total radiation from the sunshine duration values with high accuracy. This equation is commonly used to estimate the amount of energy flowing to the Earth's surface from the sunshine (Besharat et al. 2013). The application of this equation has shown that in the area of Lower Silesia, there are very strong and highly significant relationships between the amount of sunshine duration and the amount of solar energy flowing to the ground (Urban et al. 2018, Bryś et al. 2020). The described relations cause that in Wrocław, there are strong and highly significant direct connections between $\mathrm{ShWr}$ and air temperature. The analysis of relations between monthly sunshine and monthly TWr gives the results summarised in Table 2, and the course of the annual ShWr is presented in Fig. 6.

The distribution of the values of correlation coefficients indicates that in the period from March to September inclusive, sunshine and air temperature correlations in Wrocław are significant, while the correlations in the period from April to September are highly significant. Accordingly, the annual air temperature is also quite strongly and significantly associated with annual ShWr and its variability is explained by approximately $37 \%$ of TWr variance.

The largest amount of solar energy is supplied during the long-day months. This period can be defined as the period in which the length of the day during the whole month is $>12 \mathrm{~h}$. This means that the long-day period stretches from April to August inclusive. The variability of sunshine during the long-day months explains $\sim 81 \%$ of the annual sunshine variance $(\mathrm{R}=0.90)$ and about $48 \%$ of the annual temperature variance

Table 1. Values of correlation coefficients (r) between monthly and annual cloudiness in Wrocław and air temperature in Wrocław (TWr) and their statistical significance (p). Analysis period: 1951-2018.

\begin{tabular}{|c|c|c|c|c|c|c|c|c|c|c|c|c|c|}
\hline & Jan & Feb & Mar & Apr & May & Jun & Jul & Aug & Sep & Oct & Nov & Dec & Year \\
\hline $\mathrm{r}$ & 0.100 & 0.210 & -0.180 & -0.340 & -0.380 & -0.330 & -0.520 & -0.24 & -0.450 & 0.010 & 0.090 & 0.130 & 0.120 \\
\hline$p$ & 0.401 & 0.092 & 0.152 & 0.004 & 0.001 & 0.006 & 0.000 & 0.053 & 0.000 & 0.929 & 0.477 & 0.280 & 0.344 \\
\hline
\end{tabular}

Significant correlations $(p<0.05)$ are in bold type. The values of $p$ described as 0.000 mean that $p<0.001$.

Table 2. Values of correlation coefficients (r) between monthly and annual sunshine, and monthly and annual air temperature in Wrocław (1951-2018) along with their statistical significance $(p)$.

\begin{tabular}{|c|c|c|c|c|c|c|c|c|c|c|c|c|c|}
\hline & Jan & Feb & Mar & Apr & May & Jun & Jul & Aug & Sep & Oct & Nov & Dec & Year \\
\hline $\mathrm{r}$ & 0.070 & -0.110 & 0.270 & 0.640 & 0.620 & $\mathbf{0 . 6 6 0}$ & $\mathbf{0 . 8 1 0}$ & $\mathbf{0 . 7 4 0}$ & $\mathbf{0 . 6 1 0}$ & 0.140 & 0.020 & 0.140 & $\mathbf{0 . 6 1 0}$ \\
\hline$p$ & 0.583 & 0.381 & 0.025 & 0.000 & 0.000 & 0.000 & 0.000 & 0.000 & 0.000 & 0.248 & 0.847 & 0.239 & 0.000 \\
\hline
\end{tabular}

Symbols as in Table 1. 


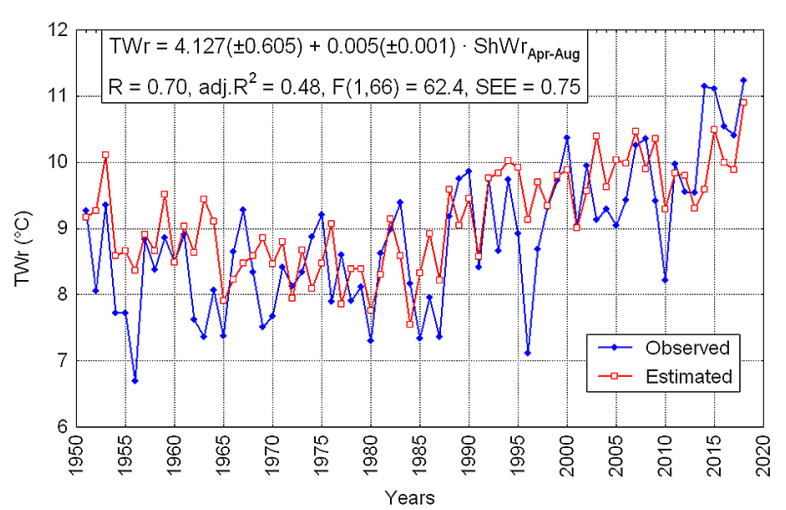

Fig. 7. The course of annual air temperature in Wrocław (TWr) and annual air temperature estimated based on long-day months of sunshine duration in Wroclaw $\left(\mathrm{ShWr}_{\text {Apr-Aug }}\right)$. The relationship between TWr and $\mathrm{ShWr} \mathrm{r}_{\text {Apr-Aug }}$ and its statistical characteristics are in the upper frame of the figure.

in Wrocław. Long-day sunshine $\left(\mathrm{ShWr}_{\mathrm{Apr}-\mathrm{Aug}}\right)$ in Wrocław is clearly more strongly correlated with the annual temperature $(r=0.70)$ than with the annual ShWr (Table 2).

A review of scatterplots and courses (Fig. 7) of the annual TWr as a linear function of $\mathrm{ShWr}_{\mathrm{Apr}}$ Aug reveals that the most important features of temperature changes, such as a rapid change of the temperature from one variability regime to another and a positive trend after 1988, are quite well represented. This proves that $\mathrm{ShWr}_{\text {Apr-Aus }}$ variability is one of the causes of TWr variability. At the same time, it can be observed that in some years, there are significant differences between the observed TWr values and the TWr values estimated from the dependencies, indicating that other factors than ShWr ered, which shape the variability of TWr.

Residual analysis revealed that the differences between the observed values of TWr and those estimated from $\mathrm{ShWr} \mathrm{r}_{\mathrm{Apr}-\mathrm{Aug}}$ are particularly large when the average temperature of the first quarter in Wrocław is either significantly lower than the average (e.g. 1956, 1963, 1969, 1996) or much higher than the average (e.g. 1974, 1975, 1989, 1990). This indicates that possibly the most important yet ignored factor is one that regulates thermal relations in the cold season of the year.

\section{The advection factor activity}

The above statement moves our search for the next variable to advection processes, which are controlled by atmospheric circulation. This sought for variable is atmospheric circulation in the cold period, in which sunshine duration does not significantly affect the variability of TWr. The NAO essentially regulates winter temperature over large areas of Europe and Poland (van Loon, Rogers 1978, Hurrell 1995, Hurrell et al. 2003, Marsz, Styszyńska 2010).

NAO is the result of climate variability within the system and results from the interaction of the ocean and atmosphere over the North Atlantic (Curry, McCartney 2001, Frankignoul et al. 2001, Czaja, Frankignoul 2002, Czaja et al. 2003). A number of studies (e.g. Cohen, Barlow 2005, Semenov et al. 2008) have shown that there are no causal relationships between increasing $\mathrm{CO}_{2}$ concentration in the atmosphere or AGW in general and NAO variability.

In winter periods (December-March), when NAO reaches the highest intensity, in the positive phase of oscillation, maritime Polar air mass heated over the Atlantic comes over Poland; it is transformed to the degree approximately inversely proportional to the value of the winter NAO Hurrell index (Hurrell 1995). Due to advection of warm maritime air, the winter temperature is higher than the climate norm, especially high when the NAO Hurrell index reaches values $>+1.0$. As a result, in the case of a series of consecutive years in which NAO is in the positive phase and the value of winter NAO index reaches higher values, a fast and relatively strong upward trend of air temperature is observed.

In the negative phase of NAO, southern circulation dominates and the relations of air temperature with the NAO index value become non-stationary, due to the possibility of advection from both the northern and eastern sector as well as the southern sector. However, cold advections are more frequent, which means that in the negative phases of NAO, cold winters in Poland prevail (Marsz 2006). With NAO values <-2.0, winters in Poland are usually much cooler than their climate norm. A series of years with negative NAO values results in a negative trend of air temperature and/or a cooling period.

The station-based winter (DJFM) NAO Hurrell index was used for the analysis of NAO relations with monthly TWr. The results of the analysis are presented in Table 3. 
Table 3. Values of correlation coefficients (r) and their statistical significance ( $p$ ) between (DJFM) winter NAO Hurrell index and monthly and annual air temperature in Wrocław (1951-2018).

\begin{tabular}{|c|c|c|c|c|c|c|c|c|c|c|c|c|c|}
\hline Month & Jan & Feb & Mar & Apr & May & Jun & Jul & Aug & Sep & Oct & Nov & Dec & Year \\
\hline r & $\mathbf{0 . 5 7 0}$ & $\mathbf{0 . 4 6 0}$ & 0.610 & 0.190 & 0.190 & 0.020 & 0.210 & $\mathbf{0 . 3 2 0}$ & 0.230 & 0.140 & -0.160 & 0.240 & $\mathbf{0 . 5 8 0}$ \\
\hline$p$ & 0.000 & 0.000 & 0.000 & 0.114 & 0.125 & 0.895 & 0.080 & 0.008 & 0.058 & 0.258 & 0.198 & 0.052 & 0.000 \\
\hline
\end{tabular}

Symbols as in Table 1.

The variability of the winter NAO Hurrell index shows, except for November, a positive correlation with the monthly temperature in Wrocław. Highly significant correlations with monthly temperature occur in the period from January to March. Additionally, there is a significant asynchronous correlation in August, which is delayed in relation to NAO. In the remaining months, the values of correlation coefficients of the NAO index with TWr are insignificant. Such correlation of the winter NAO index with monthly temperature, distributed over time, including asynchronous August correlation, is typical for the whole of Poland (Marsz, Styszyńska 2010).

The range of seasonal variations in air temperature is the largest during winter. For this reason, the variability of air temperature of the first quarter (January-March) explains (adj. $R^{2} 100 \%$ ) $57.5 \%$ the variance of annual $\mathrm{TWr}$ in the years 1951-2018. The reliable explanation of monthly temperature variability in Wrocław in the first quarter by the winter NAO index (about 50\%) is the most important reason for the strong and highly significant correlation of the winter NAO Hurrell index also with TWr.

\section{The analysis and its results}

Thus, the two variables can be used to determine the role of factors operating within the system in shaping the variability of annual TWr: sunshine duration in the long-day months in Wrocław - ShWr $\mathrm{r}_{\text {Apr-Aug }}$ and the winter NAO Hurrell index (1995) - $\mathrm{NAO}_{\mathrm{H}}$ variable. These are not all possible variables; however, these are possibly the most important ones.

Multiple regression was used to analyse the relationships between the variables, in which the explained variable was the annual TWr and the explanatory variable (independent) was sunshine duration in the long-day months $\left(\mathrm{ShWr}_{\mathrm{Apr}-\mathrm{Aug}}\right)$ and the station-based NAO Hurrell index $\left(\mathrm{NAO}_{\mathrm{H}}\right)$. The estimation of the parameters of the multiple regression equation using the least squares method produced the following result:

$$
\begin{gathered}
\mathrm{TWr}=4.8966( \pm 0.5305)+0.0039( \pm 0.0005) \times \\
\mathrm{ShWr}_{\text {Apr-Aug }}+0.1937( \pm 0.0367) \times \mathrm{NAO}_{\mathrm{H}} .
\end{gathered}
$$

There is the statistical characteristics of the equation: $\mathrm{R}$ (multiple regression correlation coefficient) $=0.80$, adj. $R^{2}$ (corrected for the number of degrees of freedom, the coefficient of determination) $=0.6290, F(2,65))=57.8($ Fisher-Snedecor test), $\mathrm{p}$ (significance of the equation) $<<0.001$, standard error of estimation $(\mathrm{SEE})=0.63$. The estimation of intercept and regression coefficients is highly statistically significant $(p<<0.001)$. The distribution of residuals is normal, and the residuals and deleted residuals are closely related linearly.

In Eq. (2), the variability $\mathrm{ShWr}$ Apr-Aug explains for $48.6 \%$ and the variability $\mathrm{NAO}_{\mathrm{H}}$ for $15.4 \%$ of the annual variance of TWr in the years 19512018. The scatterplot of the values estimated using this Eq. (2) in relation to the observed values

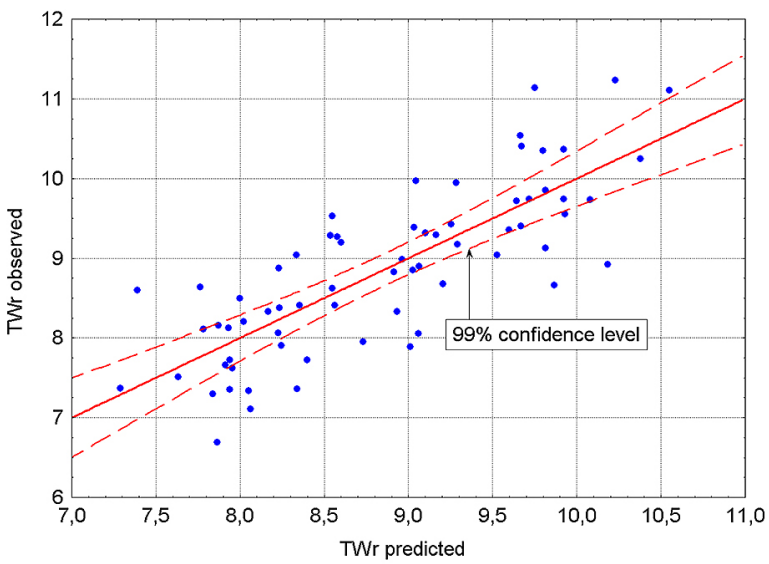

Fig. 8. The predicted (from Eq. (2)) values of annual air temperature in Wrocław (TWr) in relation to the observed values. The dotted line indicates 99\% confidence interval (1951-2018). 


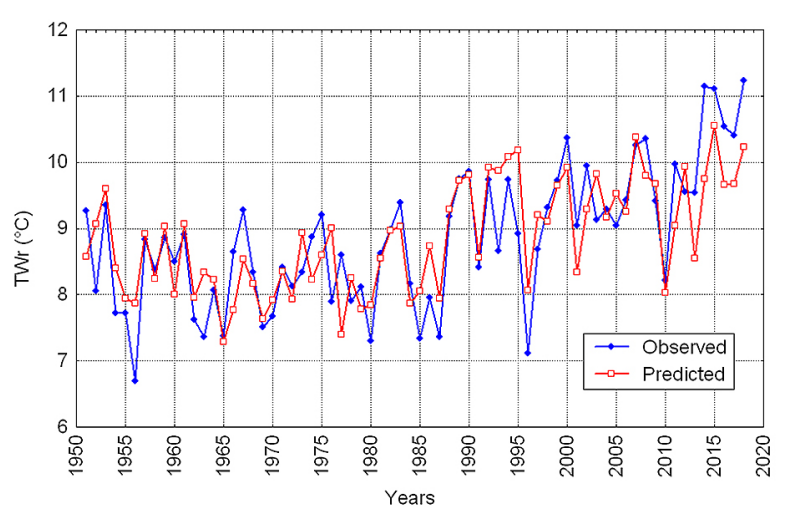

Fig. 9. The courses of the observed and predicted (from Eq. (2)) values of annual air temperature in Wrocław (TWr) in 1951-2018.

is presented in Figure 8, and the courses of the observed and calculated TWr values (using the Eq. (2)) is shown in Figure 9.

In the course of the TWr values, estimated with Eq. (2), a few cases of strong underestimation of annual temperature value (e.g. in 2013) can be noted. The residual analysis showed that these are the cases in which, with a negative NAO value in the cold period, advection of warm air from the south predominated.

A weak, statistically insignificant trend is observed in the remainder of Eq. (2), and the whole series of residuals is quite strongly $(\mathrm{r}=0.53)$ correlated with the temperature of the fourth quarter (October-December) in Wrocław. This indicates that Eq. (2) does not include an increase in air temperature occurring in this part of the year. Considering the selection of explanatory variables, it is understandable. After introducing the NAO station-based index from December as the third variable in the equation, the equation remains highly significant, but the degree of explanation of the dependent variable increases so slightly (by $2 \%$ ) that it does not justify its further complication.

The estimated TWr trend in the series of values calculated from Eq. (2) is equal to $+0.025( \pm 0.004)^{\circ} \mathrm{C}$. It is a trend of $0.009^{\circ} \mathrm{C} \cdot$ year $^{-1}$, and it is lower than the trend occurring in the observed series of annual TWr in the period in question $\left(+0.034( \pm 0.005)^{\circ} \mathrm{C} \cdot\right.$ year $\left.^{-1}\right)$. Considering the errors in estimating both trends, the difference is statistically insignificant. It can be assumed, however, that the reduced value of the annual temperature trend in Wrocław results from ignoring the influence of $\mathrm{CO}_{2}$ concentration increase in the atmosphere, giving an additional energy stream directed to the Earth's surface, which is the cause of temperature growth, that is radiative forcing (DF variable, see Eq. (1)).

The calculated values of radiative forcing according to the formula (1) for the years 1951-2018 were introduced as the third variable into Eq. (2) and the parameters of this equation (Eq. (3)) and its statistical characteristics were calculated. The obtained results are as follows:

$$
\begin{array}{r}
\mathrm{TWr}=5.396( \pm 0.509)+0.003( \pm 0.001) \times \mathrm{ShWr}_{\text {Apr-Aug }}+ \\
0.176( \pm 0.034) \times \mathrm{NAO}_{\mathrm{H}}+0.756( \pm 0.214) \times \Delta \mathrm{F} \quad \text { (3) }
\end{array}
$$

Equation (3) is highly significant $(\mathrm{F}(3,64)=49.5$, $p<0.001$ ) and all its parameters (constant term, regression coefficients) are also estimated with high significance $(p<0.001$; t-test). The multiple correlation coefficient slightly increased in relation to Eq. (1), namely by $0.036(\mathrm{R}=0.836)$; the determination coefficient increased a little more. (adj. $\left.\mathrm{R}^{2}=0.685\right)$. The SEE of the TWr value decreased slightly $(\mathrm{SEE}=0.58)$.

From the analysis of variance, it follows that, in the Eq. (3), variability $\mathrm{ShWr} \mathrm{Apr}_{\text {-Aug }}$ explains for $49 \%$, variability $\mathrm{NAO}_{\mathrm{H}}$ for $15 \%$ and variability DF for $5.9 \%$ of the variance of the annual TWr in the considered period. The trend of TWr values calculated from Eq. (3) increased and is practically the same $\left(+0.035( \pm 0.003)^{\circ} \mathrm{C} \cdot\right.$ year $\left.^{-1}\right)$ as in the series of observed values. This suggests that variable DF introduces only a better fit of the trend (in relation to the real $\mathrm{TWr}$ trend) into Eq. (3), as a manifestation of TWr variability.

A review of the graphs of series $\mathrm{TWr}, \mathrm{ShWr}_{\mathrm{Apr}}$ ${ }_{\text {Aug }}, \mathrm{NAO}_{\mathrm{H}}$ and DF, from which the trends were removed, and their comparison with the course of observed TWr values confirms the above-mentioned suggestion. Similarly, regression analysis, in which TWr devoid of the trend was the explained variable, and $\mathrm{ShWr} \mathrm{Apr}_{\text {-Aug }} \mathrm{NAO}_{\mathrm{H}}$ and $\mathrm{DF}$ were the explanatory variables from which the trend was removed, allowed us to create an equation with only two variables: The ShWr $\mathrm{rpr}_{\text {Aug }}$ and $\mathrm{NAO}_{\mathrm{H}}$ jointly explain $\sim 46 \%$ of the variance of the explained variable. The calculation program (progressive stepwise regression) eliminated the variable $\mathrm{DF}$ without trend as statistically insignificant $(p=0.939)$. 


\section{Discussion of the results and conclusions}

\section{The problem of a rapid change of the thermal regime}

The obtained results of the analysis show that variability of the three simple independent variables $\mathrm{ShWr}_{\mathrm{Apr}-\mathrm{Aug}} \mathrm{NAO}_{\mathrm{H}}$ and DF explains together $68.5 \%$ of the annual variance of the TWr in the years 1951-2018. A proportion of the explained variance is high, because without explanation is only $31.5 \%$ of the TWr variability.

It is significant, that no discontinuity in the DF course for the years 1951-2018 does not occur. On the other hand, such discontinuity, less or more distinct, in the similar courses of the two variables $\mathrm{ShWr}_{\text {Apr-Aug }}$ and $\mathrm{NAO}_{\mathrm{H}}$ occurs in the years 19871989. It explains, in the statistical sense, a radical change of the annual air temperature course in Wrocław. It is only from this time (1987-1989), we could say, that a progressive warming occurs. However, there is a question: what climatic process or a group of these processes are the reason for this warming and why since 1988 ?

The reason for the observed warming is a change in the macro-circulation conditions in the Atlantic-Eurasian circular sector, expressed as a change of the so-called circulation epochs. Circulation epochs are determined based on the changes in the structure of macro-types of central and middle tropospheric circulation (Girs 1971, Girs, Kondratovich 1978). Within a given epoch, the structure of the macro-types of the middle-tropospheric circulation $\mathrm{W}, \mathrm{E}$ and $\mathrm{C}$ (according to the classification of Wangengejm-Girs, structure of the macro-types - a proportion between frequency of the W, C and E macro-types in the examined year. The sum of these macro-types is constant and is equal to number of days in a year) is relatively constant, typical for a longer period: ten years or more. Changes in the structure lead to the transition from one epoch to the next, with a new structure of the macro-types frequency.

In the years 1951-2018, circulation epochs changed twice. Savichev et al. (2015) define the following circulation epochs: until 1965 (19491965) - The E+C Epoch, from 1966 to 1989 - The E Epoch and from 1990 to 2014 - The W Epoch (the quoted year 2014 does not indicate that circulation epoch has closed in that year. It indicates only that (Savichev et al., 2015) made of the series of macro-types frequency solely to the year 2014). Degirmendžić and Kożuchowski (2018) distinguish the same epochs in the years 1951-2018, and their limits show small shifts in relation to the limits set by Savichev et al. (2015). According to Degirmendžić and Kożuchowski (2018), the end of the E+C Epoch falls in 1969, the beginning and the end of the E Epoch, respectively, in 1970 and 1991, and the beginning of the W Epoch in 1992. In view of the different methods of defining the boundaries of macro-circulation epochs by the quoted authors and the different moments of the beginning of the analysis, these differences are of little significance.

The moment the annual air temperature regime in Wrocław changed and a strong upward trend appeared in a series happened in the years 1987-1989, which is very close to the change of the circulation epoch $\mathrm{E}$ to $\mathrm{W}$ according to Savichev et al. (2015) in 1989/1990 and according to the divisions by Degirmendžić and Kożuchowski (2018) in the years 1991/1992.

At the same time (1987-1989), a similar change in the annual air temperature regime has taken place at numerous European stations, from the French coast of the Bay of Biscay (Merignac Aeroport de Bordeaux: $44.8^{\circ} \mathrm{N}, 0.7^{\circ} \mathrm{W}$ ) to the British Isles and the southern Scandinavian. It

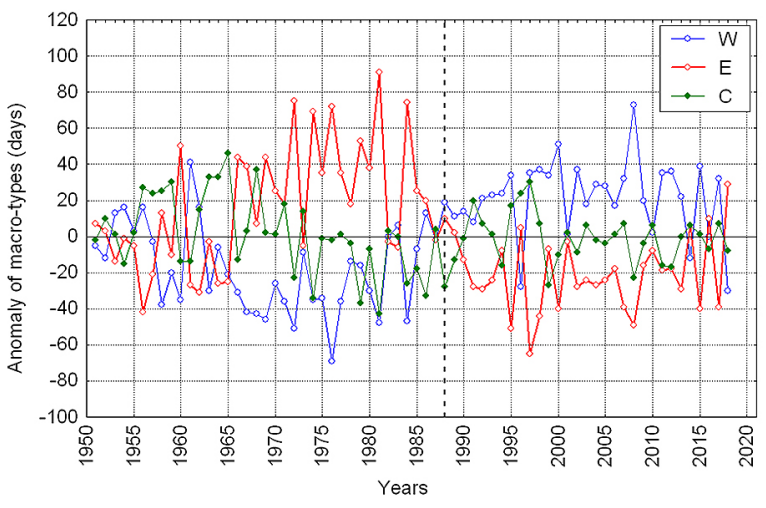

Fig. 10. The course of the anomaly of the annual frequency of W, E and C macro-types of the middletropospheric circulation according to the classification by Wangengejm-Girs. The anomalies are calculated with reference to averages from the period 19512015. The vertical dashed line marks the moment of transition of circulation epoch $\mathrm{E}$ to circulation epoch W. 
was also noted all over Germany, Switzerland and other countries of Central Europe as well as in vast areas of the Russia Lowland (Minsk, Moscow) up to Kazan $\left(55.7^{\circ} \mathrm{N}, 49.2^{\circ} \mathrm{E}\right)$ and Arkhangelsk $\left(64.3^{\circ} \mathrm{N}, 40.3^{\circ} \mathrm{E}\right)$. The change in temperature regime was also manifested at some European high mountain stations in the Alps (Saentis, Zugspitze) and in the Sudetes (Śnieżka) and the Carpathians (Kasprowy Wierch). This confirms that the revealed change in the annual temperature regime in Wrocław is a manifestation of macro-scale processes, not local processes.

The review of the annual anomaly of the attendance of $\mathrm{W}, \mathrm{E}$ and $\mathrm{C}$ macro-types in the years 1951-2018 (Fig. 10) shows that in 1987, the frequency of all three macro-types of the middle-tropospheric circulation approached the values corresponding to the multi-annual average of the period 1951-2015. After 1988, the frequency of the macro-type $\mathrm{W}$ became higher than the longterm norm, the attendance of the macro-type $\mathrm{E}$ dropped below the long-term norm and the frequency of the macro-type $\mathrm{C}$ oscillates around the long-term average.

The frequency of macro-type $\mathrm{W}$ which is higher than normal of the last circulation epoch, after 1988 , results in a change in weather structure in relation to the previous epoch. Each macro-type is associated with the occurrence of a specific synoptic situations in the lower troposphere (e.g. circulation types by (Osuchowska-Klein 1978, 1991, Fortuniak et al. 2001, Marsz 2005). Therefore after 1988, macro-type $\mathrm{W}$ weather became more common, above the multi-annual average, and at the same time, macro-type E weather types fell below the multi-annual average. Since the average values of climatic elements averaged monthly or annually depend directly on the weather structure occurring in a given month or year, the values of several climatic elements depend on the frequency of macro-types. As a result of the cause-effect chain, there are direct correlations between the frequency of $\mathrm{W}$ and $\mathrm{E}$ macro-types and air temperature and sunshine duration, as well as a weaker correlation with annual precipitation totals (PWr variable) in Wrocław (Table 4).

Lower frequency of macro-type $\mathrm{E}$ and the simultaneous increase of macro-type $\mathrm{W}$ frequency led to an increase in the sunshine (see Fig. 6), also during the long-day period, and an increase in the TWr. Since the attendance of macro-type $\mathrm{E}$ in 1986-1991 dropped rapidly (Fig. 10), sunshine duration and temperature changed accordingly. Certain influence on the rapid increase in the TWr may also be exerted by a decrease in annual precipitation along with an increase of macro-type $\mathrm{W}$ frequency and a decrease of macro-type $\mathrm{E}$ attendance (Table 4). Smaller annual precipitation and increased solar radiation reduce heat loss for evaporation (latent evaporation heat), which increases the share of sensible heat streams in turbulence exchange, boosting air temperature increase with the same radiation energy supply to the surface of the area.

The winter NAO index, which increased in the same period, also generously contributed to air temperature increase (Głogowski et al. 2020). The winter NAO index is highly significantly associated with the macro-type $W$ frequency from January to March $(r=0.51, p<<0.001)$ and less negatively with the macro-type $E$ attendance in the same pe$\operatorname{riod}(\mathrm{r}=-0.31, p=0.011 ; 1951-2018)$. As a result, the change in the frequency of macro-types $\mathrm{W}$ and E led at the same time to a strong increase in the intensity of western circulation in winter. The values of the winter NAO index increased from year to year (from +0.75 in 1987 and +0.72 in 1988 to +5.08 in 1989 and +3.96 in 1990). A large increase in the frequency of polar air advection caused an increase in temperature in winter, which in turn had a strong influence on the TWr value. The macro-type W frequency prevailed at least until 2017, above its long-term norm, and it caused the strong warming that has been going on since 1989 .

Therefore, the mechanism of temperature increase in Wrocław is linked to the increase in

Table 4. Values of correlation coefficients (r) and their statistical significance $(p)$ between the annual frequency of W, E and C macro-types of the middle-tropospheric circulation and annual air temperature (TWr), annual sunshine duration (ShWr) and sunshine duration of the long-day months. (ShWr $\left.\mathrm{Apr}_{\mathrm{Aug}}\right)$ and annual precipitation (PWr) in Wrocław (1951-2018). Markings as in Table 1.

\begin{tabular}{|c|c|c|c|c|c|}
\hline $\begin{array}{c}\text { Macro- } \\
\text { types }\end{array}$ & TWr & ShWr & ShWr $_{\text {Apr-Aug }}$ & PWr \\
\hline $\mathrm{W}$ & $\mathrm{r}$ & 0.470 & 0.620 & 0.630 & -0.310 \\
& $\mathrm{p}$ & 0.000 & 0.000 & 0.000 & 0.010 \\
\hline $\mathrm{E}$ & $\mathrm{r}$ & -0.300 & -0.600 & -0.590 & 0.330 \\
& $\mathrm{p}$ & 0.014 & 0.000 & 0.000 & 0.005 \\
\hline $\mathrm{C}$ & $\mathrm{r}$ & -0.240 & 0.090 & 0.040 & -0.100 \\
& $p$ & 0.047 & 0.488 & 0.729 & 0.431 \\
\hline
\end{tabular}


winter temperature forced by the increased attendance of the positive phase of NAO and summer temperature caused, in turn, by the increase in sunshine duration, can be consistently explained by the change of macro-circulation conditions. Both result from processes functioning within the climate system and have rather little to do with AGW in terms of causes.

\section{The role of intra-system climatic processes in shaping air temperature variability in Wrocław}

The regression analysis shows that the two independent variables together, being a manifestation of the internal dynamics of the climate system, explain about $63 \%$ of the annual variance of the TWr between 1951 and 2018. It means that all other factors that are not included in Eq. (2) but which influence the formation of the annual temperature variance over can explain at most $\sim 40 \%$ of its variability. The inclusion of radiative forcing as the third independent variable (Eq. (3)) explains that the increase in $\mathrm{CO}_{2}$ concentration in the atmosphere, i.e. the process that leads to the AGW, accounts for only $\sim 6 \%$ of the annual variance of air temperature. This last value constitutes only about $1 / 10$ of the part of the TWr variance that is explained by the effects of intra-system climatic factors.

This indicates that the variability of the annual TWr is mostly shaped by the processes resulting from the internal dynamics of the climate system and these processes play an essential role in the increase in air temperature. Two simple factors the sunshine duration of the long-day months and the winter NAO, explain together slightly $>60 \%$ of the TWr variance. The growth in sunshine duration after 1988 regulates the increase in air temperature during the months of the long-day, i.e. the warm season; the variability of the winter NAO indicator affects the air temperature during the cold season, when for purely natural reasons, the inflow of sunlight to the surface is very limited in moderate latitudes.

The increase in the heat resources in the atmosphere that causes the air temperature to rise during the warm season comes from the increased inflow of solar radiation $\left(\mathrm{ShWr}_{\mathrm{Apr}-\mathrm{Aug}}\right)$ to the ground. This is the simplest possible process leading to an increase in air temperature.
The heat causing the temperature rise during the cold season comes from the surface of the North Atlantic from where it was transported to Poland together with air masses by atmospheric circulation (NAO), raising the temperature during the winter months. The heat taken from the surface of the North Atlantic is also solar heat - it comes from short-wave radiation, which was previously absorbed and accumulated in near-surface volumes of ocean waters.

In the light of the above, the hypothesis of the dominant role of increasing $\mathrm{CO}_{2}$ concentration in the atmosphere as the main, or the only, cause of the temperature increase observed at present should be carefully addressed. Its share in explaining the annual air temperature variation in Wrocław does not exceed 6\%. The role of increasing $\mathrm{CO}_{2}$ concentration, and thus the role of human activity in shaping the currently observed increase in air temperature, seems to be definitely overestimated.

\section{Acknowledgements}

The research was funded by the internal recourses of Wroclaw University of Environmental and Life Sciences.

\section{Author's contributions}

The participation of Andrzej A. Marsz includes conceptualisation, methodology and formal analysis, Anna Styszyńska includes the investigation, visualisation, writing - original draft preparation, Krystyna Bryś includes the project administration, supervision, writing - review and editing and the participation of Tadeusz Bryś includes resources, data curation, validation.

\section{References}

BACC [BALTEX Assessment of climate change for the Baltic Sea region] Author Team, 2008. Assessment of climate change for the Baltic Sea basin. Springer Science \& Business Media, Berlin Heidelberg.

Barry R.G., Carleton A.M., 2013. Synoptic and dynamic climatology. Routledge, London. DOI 10.4324/9780203218181.

Besharat F., Dehghan A.A., Faghih A.R., 2013. Empirical models for estimating global solar radiation: A review and case study. Renewable and Sustainable Energy Reviews 21: 798-821. DOI 10.1016/j.rser.2012.12.043.

Black J.N., Bonython C.W., Prescott J.A., 1954. Solar radiation and the duration of sunshine. Quarterly Journal of the Royal Meteorological Society 80(344): 231-235. DOI 10.1002/ qj. 49708034411.

Brázdil R., Budíková M., Auer I., Böhm R., Cegnar T., Faško P., Lapin M., Gajič-Čapka M., Zaninović K., Koleva E., 
Niedźwiedź T., Ustrnul Z., Szalai S., Weber R.O., 1996. Trends of maximum and minimum daily temperatures in central and southeastern Europe. International Journal of Climatology 16(7): 765-782. DOI 10.1002/(SICI)10970088(199607)16:7<765::AID-JOC46>3.0.CO;2-O.

Bryś K., Bryś T., 2010. Reconstruction of the 217-year (17912007) Wrocław air temperature and precipitation series. Bulletin of Geography. Physical Geography Series 3: 121-171. DOI 10.2478/bgeo-2010-0007.

Bryś K., Bryś T., Głogowski A., 2019. Long-wave radiation balances of the south-west Poland. In: E3S Web of Conferences. 116: 00013. DOI 10.1051/e3sconf/201911600013.

Bryś K., Bryś T., Ojrzyńska H., Sayegh M.A., Głogowski A., 2020. Variability and role of long-wave radiation fluxes in the formation of net radiation and thermal features of grassy and bare soil active surfaces in Wrocław. Science of the Total Environment 747, 141192. DOI 10.1016/j.scitotenv.2020.141192.

Büntgen U., Myglan V.S., Ljungqvist F.C., McCormick M., Di Cosmo N., Sigl M., Jungclaus J., Wagner S., Krusic P.J., Esper J., Kaplan J.O., de Vaan M.A.C., Luterbacher J., Wacker L., Tegel W., Kirdyanov A.V, 2016. Cooling and societal change during the late antique little ice age from 536 to around 660 AD. Nature Geoscience 9: 231-236. DOI $10.1038 /$ ngeo2652.

Cohen J., Barlow M., 2005. The NAO, the AO, and global warming: How closely related? Journal of Climate 18(21): 4498-4513. DOI 10.1175/JCLI3530.1.

Curry R.G., McCartney M.S., 2001. Ocean gyre circulation changes associated with the North Atlantic Oscillation. Journal of Physical Oceanography 31(12): 3374-3400. DOI 10.1175/1520-0485(2001)031<3374:OGCCAW>2.0.CO;2.

Czaja A., Frankignoul C., 2002. Observed impact of Atlantic SST anomalies on the North Atlantic Oscillation. Journal of Climate 15(6): 606-623. DOI 10.1175/1520-0442(2002)015<0606:OIOASA>2.0.CO;2.

Czaja A., Robertson A.W., Huck T., 2003. The role of Atlantic ocean-atmosphere coupling in affecting North Atlantic Oscillation variability. In: Hurrell J.W., Kushnir Y., Ottersen G., Visbeck M. (eds), The North Atlantic Oscillation: Climatic significance and environment impact. AGU Geophysical Monograph 134: 147-172. DOI 10.1029/134GM07.

Czernecki B., Głogowski A., Nowosad J., 2020. Climate: An R package to access free in-situ meteorological and hydrological datasets for environmental assessment. Sustainability 12(1), 394. DOI 10.3390/su12010394.

Degirmendžić J., Kożuchowski K., 2018. Circulation epochs based on the Vangengeim-Girs large scale patterns (1891-2010). Acta Universitatis Lodziensis, Folia Geographica Physica 17: 7-13. DOI 10.18778/1427-9711.17.01.

Dimitrieev A.A., Belyazo V.A., 2006. Kalendarnyj katalog atmosfernykh processov po cirkumpolarnoj zonie severnogo polushariya i ikh kharakteristiki za period s 1949 po 2005 god (Calendar catalogue of atmospheric processes in the Northern Hemisphere circumpolar zone and their characteristics in the period 1949-2005). In: Dimitrieev A.A., Belyazo V.A. (eds.), Kosmos, planetarnaya klimaticheskaya izmenchivost' $i$ atmosfera polarnykh regionov (Cosmos, Planetary Climatic Variability, and Atmosphere of the Polar Regions). Gidrometeoizdat, St. Petersburg: 259-336.

Dubicka M., 1994. Wptyw cyrkulacji atmosfery na kształtowanie warunków klimatu (na przykładzie Wroctawia). Studia Geograficzne 60, Acta Universitatis Wratislaviensis, 02396661, no. 1581, 295.
Dubicka M., Pyka J., 2001. Wybrane zagadnienia klimatu Wrocławia w XX wieku (Selected problems of climate in Wrocław during the 20th century). Prace i Studia Geograficzne 29: 101-112.

Dubicki A., Dubicka M., Szymanowski M., 2002. Klimat Wrocławia. In: Smolnicki K., Szykasiuk M. (eds.), Środowisko Wroctawia: Informator 2002. Dolnośląska Fundacja Ekorozwoju, Wrocław: 9-25.

Fortuniak K., Kożuchowski K., Żmudzka E., 2001. Trendy i okresowość zmian temperatury powietrza w Polsce w drugiej połowie XX wieku. Przeglad Geofizyczny 46(4): 283-303.

Frankignoul C., de Coëtlogon G., Joyce T.M., Dong S., 2001. Gulf Stream variability and ocean-atmosphere interactions. Journal of Physical Oceanography 31(12): 3516-3529. DOI $10.1175 / 1520-0485(2002) 031<3516$ :GSVAOA>2.0. $\mathrm{CO} ; 2$.

Girs A.A., 1971. Mnogoletniie kolebaniia atmosfernoi cirkulacii $i$ dolgosrochnye gidrometeorologicheskye prognozy. Gidrometeoizdat, Leningrad.

Girs A.A., Kondratovich K.V., 1978. Metody dolgosrochnykh prognozov pogody. Gidrometeoizdat, Leningrad.

Głogowski A., Bryś K., Bryś T., 2020. Influence of NAO on forming the UTCI index in Kłodzko. Theoretical and Applied Climatology 142: 1555-1567. DOI 10.1007/s00704020-03340-y.

Hu F.S., Brown T.A., Curry B.B., Engstrom D.R., 2001. Pronounced climatic variations in Alaska during the last two millennia. PNAS 98(19): 10552-10556. DOI 10.1073/ pnas.181333798.

Hurrell J.W., 1995. Decadal trends in the North Atlantic Oscillation: regional temperatures and precipitation. Science 269(5224): 676-679. DOI 10.1126/science.269.5224.676.

Hurrell J.W., Kushnir Y., Ottersen G., Visbeck M., 2003. The North Atlantic Oscillation: climatic significance and environmental impact. Geophysical Monograph 134, American Geophysical Union, Washington D.C. DOI 10.1029/ GM134.

IPCC [Intergovernmental Panel on Climate Change], 2001. Chapter 6. Radiative forcing of climate change. In: Houghton J.T., Ding Y., Griggs D.J., Noguer M., van der Linden P.J., Dai X., Maskell K., Johnson C.A. (eds.), TAR Climate change 2001: The scientific basis. Contribution of Working Group I to the Third Assessment Report of the Intergovernmental Panel on Climate Change. Cambridge University Press, Cambridge and New York: 350-416.

IPCC [Intergovernmental Panel on Climate Change], 2007. Technical summary. In: Solomon S., Qin D., Manning M., Chen Z., Marquis M., Averyt K.B., Tignor M., Miller H.L. (eds.), Climate change 2007: The physical science basic. Contribution of Working Group I to the Fourth Assessment Report of the Intergovernmental Panel on Climate Change. Cambridge University Press, Cambridge and New York: 1-91.

IPCC [Intergovernmental Panel on Climate Change], 2014. Climate change 2014 synthesis report. Contribution of Working Groups I, II and III to the Fifth Assessment Report of the Intergovernmental Panel on Climate Change. IPCC, Geneva Switzerland: 1-151.

Kopp G., Krivova N., Wu C.J., Lean J., 2016. The impact of the revised sunspot record on solar irradiance reconstructions. Solar Physics 291(9-10): 2951-2965. DOI 10.1007/ s11207-016-0853-x.

Kożuchowski K., Żmudzka E., 2001. Ocieplenie w Polsce: skala i rozkład sezonowy zmian temperatury powietrza 
w drugiej połowie XX wieku. Przeglad Geofizyczny 46(12): 81-90.

Kwiatkowski J., 1975. Zasięg fenów sudeckich i ich wpływ na mezoklimat regionów południowo-zachodniej i środkowej Polski. Przeglad Geofizyczny 20(1): 15-30.

Mann M.E., 2002. Medieval climatic optimum. In: Munn T. (ed.), Encyclopedia of global environmental change, Vol. 1. The Earth system: physical and chemical dimensions of global environmental change. John Willey \& Sons, Ltd, Chichester: 514-516.

Marsz A.A., 2005. Czy cyrkulacja atmosferyczna jest zdeterminowana i przewidywalna?. In: Bogdanowicz E., Kossowska-Cezak U., Szkutnicki J. (eds.), Ekstremalne zjawiska hydrologiczne i meteorologiczne. Wyd. PTGeof. i IMGW, Warszawa: 32-51.

Marsz A.A., 2006. W sprawie niektórych interpretacji skutków działania Oscylacji Północnego Atlantyku (NAO). Czasopismo Geograficzne 77(1): 220-228.

Marsz A.A., Styszyńska A., 2010. Changes in sea surface temperature of the South Baltic Sea (1854-2005). In: Przybylak R., Majorowicz J., Brázdil R., Kejna M. (Eds.), The Polish climate in the European context: An historical overview. Springer, Netherlands: 355-374. DOI 10.1007/97890-481-3167-9_16.

Nazarov A.N., Myglan V.S., Orlova L.A., Ovchinnikov I.Y., 2016. Activity of Maly Aktru Glacier (Central Altai) and changes tree line fluctuations in its basin for a historical period. Ice and Snow 56(1): 103-118. DOI 10.15356/20766734-2016-1-103-118.

Ojrzyńska H., 2015. Cyrkulacyjne uwarunkowania przestrzennego rozkładu temperatury powietrza w terenie zróżnicowanym morfologicznie na przykładzie Sudetów. Rozprawy Naukowe Instytutu Geografii i Rozwoju Regionalnego Uniwersytetu Wrocławskiego 36.

Oreopoulos L., Mlawer E., Delamere J., Shippert T., Cole J., Fomin B., Iacono M., Jin Z., Li J., Manners J., 2012. The continual intercomparison of radiation codes: Results from phase I. Journal of Geophysical Research, Atmospheres 117(D6), D06118. DOI 10.1029/2011JD016821.
Osuchowska-Klein B., 1978. Katalog typów cyrkulacji atmosferycznej. Wydawnictwa Komunikacji i Łączności, Warszawa.

Osuchowska-Klein B., 1991. Katalog typów cyrkulacji atmosferycznej (1976-1990). IMGW, Warszawa.

Philipona R., Behrens K., Ruckstuhl C., 2009. How declining aerosols and rising greenhouse gases forced rapid warming in Europe since the 1980s. Geophysical Research Letters 36(2), L02806. DOI 10.1029/2008GL036350.

Savichev A.I., Mironicheva N.P., Tsepelev V.Y., 2015. Osobennosti kolebaniy atmosfernoy tsirkulyatsii $\mathrm{v}$ atlantiko-yevraziyskom sektore polushariya za posledniye desatiletiya. Uchenye Zapiski RGGMU 39: 120-131.

Semenov V.A., Latif M., Jungclaus J.H., Park W., 2008. Is the observed NAO variability during the instrumental record unusual? Geophysical Research Letters 35(11), L11701. DOI 10.1029/2008GL033273.

Szymanowski M., 2004. Miejska wyspa ciepta we Wrocławiu. Wydawnictwo Uniwersytetu Wrocławskiego, Wrocław.

Szymanowski M., 2005. Interactions between thermal advection in frontal zones and the urban heat island of Wrocław, Poland. Theoretical and Applied Climatology 82: 207-224. DOI 10.1007/s00704-005-0135-2.

Urban G., Migała K., Pawliczek P., 2018. Sunshine duration and its variability in the main ridge of the Karkonosze Mountains in relation to with atmospheric circulation. Theoretical and Applied Climatology 131: 1173-1189. DOI 10.1007/s00704-017-2035-7.

Ustrnul Z., 2006. Spatial differentiation of air temperature in Poland using circulation types and GIS. International Journal of Climatology 26(11): 1529-1546. DOI 10.1002/ joc.1393.

van Loon H., Rogers J.C., 1978. The seesaw in winter temperatures between Greenland and Northern Europe. Part I: General description. Monthly Weather Review 106(3): 296-310. DOI 10.1175/1520-0493(1978)106<0296:TSIWT$\mathrm{B}>2.0 . \mathrm{CO} ; 2$.

Wójcik R., Miętus M., 2014. Niektóre cechy wieloletniej zmienności temperatury powietrza w Polsce (1951-2010). Przeglad Geograficzny 86(3): 339-364. DOI 10.7163/ PrzG.2014.3.3. 